\title{
HUBUNGAN JARAK PENAMPUNGAN TINJA DENGAN KUALITAS MIKROBIOLOGIS (Coliform) AIR SUMUR GALI DI DESA SUMAMPIR KECAMATAN REMBANG KABUPATEN PURBALINGGA TAHUN 2017
}

\author{
Indi Lulu Diyani *), Lagiono **), Marsum ***) \\ Jurusan Kesehatan Lingkungan, Politeknik Kesehatan Kemenkes Semarang, \\ Jl.Raya Baturaden KM 12 Purwokerto, Indonesia
}

\begin{abstract}
Abstrak
Sumur gali merupakan sarana penyediaan air bersih yang digunakan oleh masyarakat untuk memenuhi kebutuhan sehari-hari. Kualitas air bersih harus memenuhi syarat mikrobiologis. Penelitian ini bertujuan untuk mengetahui hubungan jarak penampungan tinja dengan kualitas mikrobiologis (Coliform) air sumur gali di Desa Sumampir Kecamatan Rembang Kabupaten Purbalingga. Jenis penelitian yang digunakan yaitu Observasional dengan pendekatan Cross Sectional, penelitian ini dilakukan untuk mendapatkan ada tidaknya hubungan jarak penampungan tinja dengan kualitas mikrobiologis (Coliform) air sumur gali. Kandungan Coliform air bersih dibandingkan dengan Permenkes No.416/ MENKES/PER/IX/1990 tentang Syarat-syarat dan Pengawasan Air. pemeriksaan kandungan Coliform diperiksa di Laboratorium Kesehatan Kabupaten Purbalingga. Hasil penelitian jarak penampungan tinja dengan kualitas mikrobiologis (Coliform) air sumur gali di Desa Sumampir Kecamatan Rembang Kabupaten Purbalingga dari 39 sampel, sebanyak 8 (20.5\%) memenuhi syarat $(>11 \mathrm{~m})$ dan 31 (79.5\%) tidak memenuhi syarat $(<11 \mathrm{~m})$. Hasil analisis hubungan jarak penampungan tinja dengan kualitas mikrobiologis (Coliform) air sumur gali menggunakan Regresi Linear menunjukkan nilai $\rho 0,09>0,05$, sehingga dapat disimpulkan tidak ada hubungan jarak penampungan tinja dengan kualitas mikrobiologis (Coliform) air sumur gali. Saran yang diberikan kepada masyarakat, masyarakat harus memperhatikan keadaan sanitasi disekitar sumur gali, dengan selalu menjaga kebersihan sumur gali.

Kata Kunci : : Kualitas Air Sumur Gali, Penampungan Tinja dan Coliform
\end{abstract}

\begin{abstract}
Dug wells are a means of providing clean water used by the community to meet daily needs. The quality of clean water must meet the microbiological requirements. This study aims to determine the relationship of fecal stool distance with microbiological quality (Coliform) digging well water in Sumampir Village, Rembang District Purbalingga Regency. The type of research used is Observational with Cross Sectional approach, this research is done to get the existence of relation of feces shelter distance with microbiological quality (Coliform) well water dug. Number of Coliform clean water compared with Permenkes No.416/MENKES/PER/IX/1990 on Conditions and Water Supervisors. Distance measurements were made using meter, dug well construction and welldug user behavior using check list and examination of Coliform content checked in Health Laboratory of Purbalingga Regency.The results of the study of stool faults with microbiological quality (Coliform) of dug well water in Sumampir Village, Rembang District Purbalingga Regency from 39 samples, 8 (20.5\%) qualified (> $11 \mathrm{~m})$ and 31 (79.5\%) were not eligible ( $<11 \mathrm{~m})$.
\end{abstract}

\footnotetext{
"Email: indiluludiyani@gmail.com

${ }^{* *}$ Email: lagionoabdulwahid@yahoo.com

${ }^{* * *)}$ Email: marsumrahma@gmail.com
} 
The result of analysis of the relation of feces stool distance with microbiological quality (Coliform) of dug well water using Linear Regression showed value $\rho 0,09>0,05$, so it can be concluded there is no relation of fecal stool distance with microbiological quality (Coliform) of dug well water.Suggestion given to the society, the public should pay attention to the sanitary conditions around the well digging, by always maintaining the cleanliness of dug wells

Keyword : Dug well water quality, latrines and Coliform

\section{Pendahuluan}

Air merupakan salah satu sumber daya alam, bagi kehidupan yang memiliki fungsi sangat penting bagi kehidupan manusia. Fungsi air bagi manusia yaitu untuk memajukan kesejahteraan umum, sehingga merupakan modal dasar dan faktor utama pembangunan serta merupakan komponen lingkungan hidup yang penting bagi kelangsungan hidup manusia dan makhluk hidup lainnya (Peraturan Pemerintah R.I Nomor 82 Tahun 2001).

Berdasarkan Peraturan Menteri Kesehatan Republik Indonesia Nomor 416 Tahun 1990, tentang syaratsyarat dan pengawasan kualitas air. Dalam peraturan tersebut dijelaskan bahwa air bersih dan air minum harus memenuhi syarat kesehatan, baik syarat fisika, kimia, dan syarat radioaktif, dan syarat bakteriologis. Air bersih adalah air yang digunakan untuk keperluan sehari-hari yang kualitasnya memenuhi syarat kesehatan dan dapat diminum apabila telah dimasak.

Menurut Lud Waluyo (2005, h.129) sumbersumber air yang ada di bumi, dapat berasal dari air permukaan, air tanah dan mata air.

Air permukaan yang mengalir di permukaan bumi akan membentuk air permukaan. Air umumnya mendapat pengotoran selama pengalirannya. Pengotoran tersebut misalnya oleh lumpur, batangbatang kayu, daun-daun, kotoran industri dan lain sebagainya. Dengan adanya pengotoran ini menyebabkan kualitas air permukaan menjadi berbeda-beda.Pengotoran ini dapat secara fisik, kimia, dan bakteriologi (biologi). Setelah megalami pengotoran, pada suatu saat air permukaan akan mengalami pembersihan.Secara umum, air permukaan dibagi menjadi air sungai dan air rawa atau danau. Air sungai pada umumnya mempunyai derajat pengotoran yang tinggi sekali. Selain itu, pada air danau kebanyakan berwarna yang disebabkan oleh zat-zat organik yang telah membusuk.

Air tanah secara umum terbagi menjadi tiga air tanah dangkal, air tanah dalam dan mata air. Air tanah dangkal terjadi karena daya proses peresapan air dari permukaan tanah. Lumpur akan tertahan, demikian pula dengan sebagian bakteri, sehingga air tanah akan jernih tetapi lebih banyak mengandung zat kimia (garam-garam yang terlarut) karena melalui lapisan tanah yang mempunyai unsur-unsur kimia tertentu untuk masing-masing lapisan tanah. Lapisan tanah di sini berfungsi sebagai saringan. Selain penyaringan, pengotoran juga masih terus berlangsung, terutama pada muka air yang dekat dengan muka tanah, setelah menemui lapisan rapat air, air yang akan terkumpul merupakan air tanah dangkal dimana air tanah ini dimanfaatkan untuk sumber air minum melalui sumursumur dangkal. Air tanah dangkal memiliki kedalaman sampai 15 meter.

Air tanah dalam terdapat pada lapis rapat air yang pertama. Pengambilan air tanah dalam lebih sulit dari pada air tanah dangkal. Suatu lapis rapat air biasanya didapatkan pada kedalaman 100-300 meter. Bila tekanan air tanah dalam besar, maka air dapat menyembur keluar dan dalam keadaan ini dinamakan air artesis. Pada umumnya kualitas air tanah dalam lebih baik dari pada air tanah dangkal, karena terjadi penyaringan yang lebih sempurna terutama untuk bakteri. Kualitas air tanah dalam masih sedikit dipengaruhi oleh perubahan musim.

Mata air yaitu air tanah yang keluar dengan sendirinya ke permukaan tanah. Mata air yang berasal dari air tanah dalam, hampir tidak terpengaruhi oleh musim dan memiliki kualitas yang sama dengan air tanah dalam.

Air atmosfir dalam keadaan murni, sangat bersih tetapi sering terjadi pengotoran karena industri, debu, dan lain sebagainya. Oleh karena itu, untuk menjadikan air hujan sebagai sumber air minum hendaknya pada waktu menampung air hujan jangan dimulai pada saat hujan au turun, karena masih banyak mengandung kotoran. Air hujan memiliki sifat agresif terutama terhadap pipa-pipa penyalur air seperti bakbak reservoir, sehingga hal ini mempercepat terjadinya karatan (korosi). Air hujan juga memiliki sifat lunak, sehingga akan boros terhadap pemakaian sabun.

Sumur gali merupakan sumber utama persediaan air bersih bagi penduduk yang tinggal di daerah pedesaan maupun perkotaan indonesia. Kualitas air sumur gali dapat tercemar oleh bermacam-macam faktor, diantaranya oleh limbah rumah tangga/industri, sampah, tinja dan oleh karena pembuatan jamban yang kurang baik/tidak memenuhi kaidah teknis dan terbuka. Sumur gali yang sudah digunakan dalam waktu relatif lama lebih besar kemungkinan mengalami pencemaran, karena selain bertambahnya sumber pencemar juga lebih mudahnya sumber pencemar merembes kedalam sumur mengikuti aliran air tanah yang memusat ke arah sumur (Novel H.Tendean, 2012, h.2).

Faktor-faktor yang menyebabkan kualitas mikrobiologis air sumur gali kurang baik yaitu jarak septic tank, kondisi fisik septic tank, dan jenis tanah. Jarak septic tank dengan sumur gali kurang dari 11 meter, kondisi fisik septic tank yang tidak kedap air, 
tanah yang berpasir (Nurmala Febriyanti Radjak, 2012, h.2).

Menurut Rahayu Sri Pujiati (2009, h.29) pembuatan septic tank harusnya memenuhi syarat fisik, agar bakteri di dalamnya tidak keluar dari septic tank. Adapun persyaratan kondisi fisik utama septic tank yang harus dipenuhi yaitu pipa ventilasi, dinding septic tank terbuat dari tembok yang kedap air (disemen), pipa penghubung sebagai tempat masuk dan keluarnya air, tutup septic tank terbuat dari beton (kedap air).

Menurut Ehlers \& Steel (Soeparman \& Suparmin, 2002, h.55) hasil studi literatur menyatakan bahwa terdapat keragaman yang besar dalam metode pembuangan tinja di seluruh dunia. Karakteristik jamban sangat berbeda-beda. Namun, dari segi teknik murni, disepakati bahwa jamban atau metode pembuangan lainnya harus memenuhi persyaratan antara lain, tanah permukaan tidak boleh terkontaminasi, tidak boleh terjadi kontaminasi pada air tanah yang mungkin memasuki mata air atau sumur, tidak boleh terjadi kontaminasi air permukaan, tinja tidak boleh terjangkau oleh lalat dan hewan lain, tidak boleh terjadi penanganan tinja segar; atau, bila bila memang benar-benar diperlukan, harus dibatasi seminimal mungkin, jamban harus bebas dari bau atau kondisi yang tidak sedap dipandang., metode pembuatan dan pengoperasian harus sederhana dan tidak mahal.

Pencemaran kembali sangat tergantung pada tingkah laku atau kebiasaan masyarakat atau orang dalam penanganan air bersih. Tahap-tahap tersebut, antara lain, pengambilan air dan sarana air bersih misalnya sumur gali dapat memakai timba. Apabila pengambilan air dengan timba, maka timba tersebut harus timba khusus untuk sumur itu. Tali timbanya tersebut harus timba khusus untuk sumur itu. Tali timbanya tetap bersih dan setelah selesai dipakai maka timba dan tali harus digantung pada gantungan tertentu. Timba tali tidak boleh diletakkan di lantai sumur, pengangkutan air dapat memakai ember atau tempat atau wadah air atau gentong dan lain-lain yang bersih. Wadah air harus tertutup, jangan dimasukkan benda-benda atau daun-daun (biasanya dipakai untuk mencegah tumpah dalam perjalanan). Pipa atau selang yang digunakan untuk mengalirkan air jangan ada kebocoran dan tidak terendam dalam air yang kotor. Tangki air atau sejenisnya perlu diperhatikan agar tangki tersebut selalu bersih, dan jangan digunakan untuk mengangkut air kotor atau cairan lain, selang dari tangki tersebut harus selalu bersih,penyimpanan air di rumah biasanya menggunakan gentong atau tempayan. Gentong atau tempayan harus mempunyai tutup yang rapat, bersih dan mudah dibersihkan. Paling sedikit setiap satu minggu supaya dibersihkan atau dikuras. Tempayan ditempatkan di tempat yang tidak mudah tercemari dari lantai, jauh dari tempat sampah. Pengambilan air dari tempat penyimpanan dapat menggunakan kran atau gayung. Apabila menggunakan gayung, gayung tersebut harus bersih setelah pengambilan air selesai, tempat penyimpanan tersebut ditutup kembali.

Penyediaan air bersih yang tidak memenuhi syarat mikrobiologis, secara langsung maupun tidak langsung dapat menimbulkan penyakit (water borne diseases). Salah satu penyakit akibat buruknya kualitas air bersih yaitu penyakit diare. Kejadian diare dapat disebabkan oleh adanya bakteri pencemar air (coliform). Lingkungan yang berpotensi mencemari air sumur gali salah satunya adalah septic tank. Dalam septic tank terdapat tinja manusia dan di dalam tinja manusia terdapat bakteri coliform yang dapat mencemari air.

Menurut Fawanri Herwin Sinabang (2009, h.20) penyebaran bakteri Coliform termasuk di dalamnya Escheria Coli dari sumber pencemar ke air sumur gali dipengaruhi oleh beberapa faktor antara lain, jenis tanah, aliran air tanah, jarak penampungan tinja dengan sumur gali, konstruksi sumur gali, perilaku pengguna sumur gali dan kondisi fisik penampungan tinja.

Jenis tanah yang berbeda akan berbeda pula daya kandungan dan daya melewatnya air. Daya kandungan atau kemampuan tanah untuk menyimpan air disebut porositas. Umumnya dinyatakan dalam prosen atau rasio antara pori-pori tanah dengan volume total tanah. Kemampuan tanah untuk melewatkan air disebut permaebilitas yaitu jumlah air yang dapat dilewatkan oleh lapisan tanah dalam satuan luas penampang.

Didalam siklus hidrologi maka air tanah secara alami mengalir kareda adanya perbedaan tekanan dan letak ketinggian lapisan tanah. Air akan mengalir dari tempat yang tinggi ke tempat yang rendah. Oleh karena itu, apabila letak sumur gali berada di bawah dari letak sumber pencemar maka bahan pencemar bersama aliran air tanah akan mengalir untuk kemudian mencapai sumur gali. Penentuan lokasi pembuatan sumur yang jauh dari sumber pencemar merupakan usaha untuk mencegah dan mengurangi resiko terhadap pencemaran.

Kontaminasi bakteri tidak dapat bergerak melawan arus atau bertentangan dengan aliran air tanah. Jarak sumur gali minimal 11 meter dari sumber pencemaran seperti jamban, septic tank, air kotor atau comberan, tempat pembuangan sampah, kandang ternak, serta tempat kotoran ternak.

Kondisi sumber air ada yang memenuhi syarat ada yang tidak memenuhi syarat, hal tersebut dapat dilihat dari lokasinya seperti jarak terhadap sumber pencemar dan konstruksinya. Untuk mencegah terjadinya pencemaran bakteri Coliform termasuk di dalamnya Escheria coli terhadap air sumur gali maka diperlukan konstruksi sumur yang memenuhi persyaratan sanitasi.

Pencemaran dapat terjadi, karena perilaku atau kebiasaan masyarakat dalam penanganan air bersih. Contohnya pengambilan air, pengangkutan air dan penyimpanan air yang tidak memenuhi syarat/ tidak memperhatikan hygiene sanitasi. 
Kondisi fisik penampungan tinjadapat menyebabkan pencemaran air, karena bakteri (Coliform) yang terdapat di dalam penampungan tinja dapat keluar dari penampungan tinjaapabila kondisi penampungan tinja tidak memenuhi syarat.

Menurut Lud Waluyo (2005, h.118) air dapat memberikan manfaat yang menguntungkan dan memberikan dampak negatif bagi kesehatan manusia. Air yang tidak memenuhi persyaratan dapat menjadi media penularan penyakit yang sangat baik. Air penduduk yang telah tercemar oleh bakteri penyebab berbagai penyakit, dapat ditularkan kepada manusia atau hewan melalui 4 mekanisme yaitu water borne mechanism, water washed mechanism, water based mechanism dan insect vector mechanism.

Bakteri Coliform merupakan bakteri gram negatif yang meragi laktosa pada suhu $35^{\circ} \mathrm{C}$ dalam waktu 24 jam atau 48 jam dengan menghasilkan gas dan asam. Bakteri Coliform berbentuk batang dan tidak membentuk spora. Bakteri Coliform di dalamnya terdapat bakteri Escheria Coli dan bakteri patogen lainnya yang dapat menyebabkan penyakit (Lud Waluyo, 1995, h.31). Kehadiran Coliform di dalam air dapat dijadikan indikator pencemar biologis. Bila bakteri Coliform terdapat pada suatu benda menandakan benda tersebut telah tercemar oleh materi fekal (tinja, feses manusia). Hal ini disebabkan bakteri ini berasal dari tinja manusia dan hewan-hewan berdarah panas lainnya (Lud Waluyo, 1995, h.110).

Persyaratan mikrobiologi air sesuai dengan Peraturan Menteri Kesehatan Republik Indonesia Nomor 416 Tahun 1990, kadar maksimum yang diperoleh pada air bersih, MPN (The Most Probable Number) Coliform adalah sebesar 50/100 ml.

Frisian Lufthi intan Risqita (2016, h.1) dalam penelitiannya di Desa Pangebatan Kecamatan Karanglewas Kabupaten Banyumas menyatakan bahwa hasil pemeriksaan laboratorium kandungan bakteriologi air air sumur gali yang diperiksa tidak memenuhi syarat kesehatan sesuai dengan ketentuan Peraturan Menteri Kesehatan Republik Indonesia Nomor 416 Tahun 1990 dan hasil penelitian menunjukan adanya hubungan yang signifikan antara jarak sumber pencemar dengan kualitas mikrobiologis air sumur gali.

Berdasarkan data dari Dinas Kesehatan Kabupaten Purbalingga tahun 2015 bahwa penyakit diare masih merupakan salah satu penyebab kematian bayi dan balita. Dari perkiraan 19.133 kasus diare pada tahun 2015 terdapat kejadian kasus diare sebesar 22.644 kasus (118,35\%) yang ditangani, bila dibandingkan dengan tahun 2014 sebesar 75,20\% mengalami peningkatan penemuan kasus. Pada tahun 2015 penyakit diare dengan angka kejadian tertinggi 1269 kasus dengan IR 214 per 1000 penduduk di Kecamatan Rembang.

Berdasarkan data dari Puskesmas Rembang tahun 2015, penyakit diare tertinggi Kecamatan Rembang yaitu berada di Desa Sumampir dengan jumlah 1764 kasus. Data dari Balai Desa Sumampir bahwa sumber air bersih yang digunakan adalah sumur gali, PDAM dan mata air dengan menggunakan selang. Jumlah sumur gali dan penampungan tinja terbanyak berada di dusun 2 yaitu sebanyak 356 sumur gali dan 589 penampungan tinja. Dari survey awal jarak sumur gali rata-rata dekat dengan penampungan tinja dan konstruksi penampungan tinja tidak memenuhi syarat seperti dinding penampungan tinja yang tidak kedap air.

Berdasarkan uraian diatas maka peneliti tertarik untuk melakukan penelitian dengan judul "Hubungan Jarak Penampungan Tinja dengan Kualitas Mikrobiologis (Coliform) Air Sumur Gali di Desa Sumampir Kecamatan Rembang Kabupaten Purbalingga Tahun 2017”.

Adakah hubungan antara jarak penampungan tinja dengan kualitas mikrobiologis (Coliform) air sumur gali di Desa Sumampir Kecamatan Rembang Kabupaten Purbalingga tahun 2017? Untuk mengukur jarak penampungan tinja dengan sumur gali di Desa Sumampir Kecamatan Rembang Kabupaten Purbalingga, memeriksa kualitas mikrobiologis (Coliform) air sumur gali di Desa Sumampir Kecamatan Rembang Kabupaten Purbalingga, menganalisis hubungan jarak penampungan tinja dengan kualitas mikrobiologis (Coliform) air sumur gali di Desa Sumampir Kecamatan Rembang Kabupaten Purbalingga, menganalisis hubungan konstruksi sumur gali dengan kualitas mikrobiologis (Coliform) air sumur galidi Desa Sumampir Kecamatan Rembang Kabupaten Purbalingga dan menganalisis hubungan perilaku pengguna sumur gali dengan kualitas mikrobiologis (Coliform) air sumur gali di Desa Sumampir Kecamatan Rembang Kabupaten Purbalingga. Manfaat penelitian ini:

1. Bagi masyarakat

Sebagai informasi bagi masyarakat umumnya Kabupaten Purbalingga, khususnya masyarakat di Desa Sumampir tentang faktor-faktor yang berhubungan dengan kualitas mikrobiologis (coliform) air sumur gali.

2. Bagi Dinas Kesehatan Kabupaten Purbalingga

Memberikan informasi dan bahan masukan evaluasi program pengawasan kualitas air sumur gali.

3. Bagi Institusi

Menambah kepustakaan bagi perpustakaan Poltekkes Kemenkes Semarang Kampus VII khususnya Jurusan Kesehatan Lingkungan.

4. Bagi Peneliti

Menambah wawasan dan pengetahuan penulis khususnya bidang ilmu Kesehatan Lingkungan. 


\section{Struktur Hubungan Variabel}

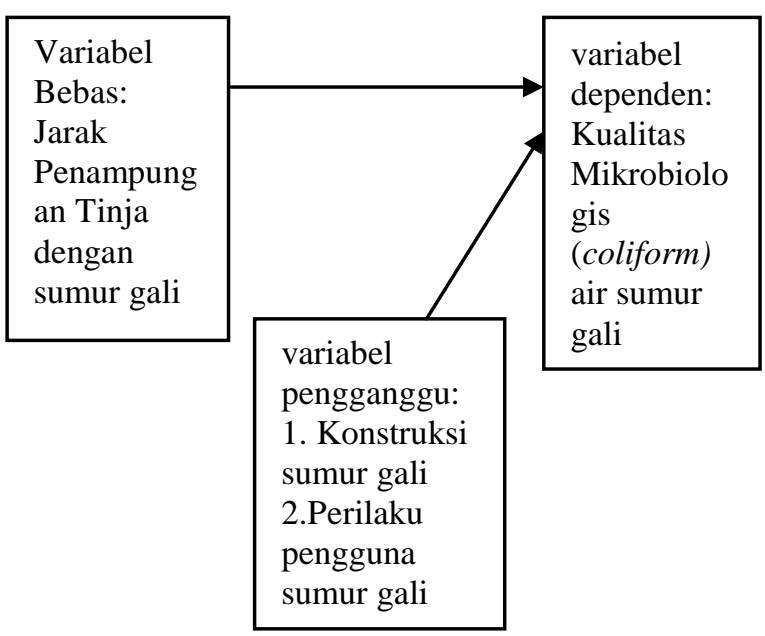

\section{Bahan dan Metode}

Jenis Penelitian ini menggunakan studi Observasional dengan pendekatan Cross Sectional, dengan arti rancangan studi ini mempelajari tentang korelasi antara jarak penampungan tinja dengan kualitas mikrobiologis (Coliform) air sumur gali. Penelitian dilakukan dengan cara Jenis Penelitian ini menggunakan studi Observasional dengan pendekatan Cross Sectional, dengan arti rancangan studi ini mempelajari tentang korelasi antara jarak penampungan tinja dengan kualitas mikrobiologis (Coliform) air sumur gali.

Hipotesispenelitian adalah ada hubungan antara jarak penampungan tinja dengan kualitas mikrobiologis (Coliform) air sumur gali di Desa Sumampir Kecamatan Rembang Kabupaten Purbalingga Tahun 2017.

Lokasi penelitian dilakukan di Desa Sumampir Kecamatan Rembang Kabupaten Purbalingga dan waktu pelaksanaan pada bulan Maret-Mei 2017.

Populasi penelitian ini adalah jumlah sumur gali sebanyak 356 sumur gali. Besaran sampel 39 sampel,.pengambilan sampel sebagai berikut :

1. Mengkriteria inklusikan sampel, antara lain:

a. Posisi sumur gali lebih rendah dari penampungan tinja.

b. Jarak sumur gali dengan kandang ternak > $11 \mathrm{~m}$

c. Jarak sumur gali dengan Saluran pembuangan air limbah $>11 \mathrm{~m}$.

d. Jarak sumur gali dengan Pembuangan sampah $>11 \mathrm{~m}$.

2. Perhitungan besarnya sampel dengan rumus uji korelasi yaitu:

dimana:

$$
\mathrm{n}=\left\{\frac{Z \alpha+Z \beta}{0,5 \ln [(1+r) /(1-r)]}\right\}^{2}+3
$$

$\mathrm{n}=$ besar sampel

$\mathrm{z} \alpha=$ adjusted standar deviation untuk uji dua arah $(1,96)$
$\mathrm{Z} \beta=$ adjusted standar deviation untuk $\beta$ ( $\beta$

$$
\mathrm{Z}=0,84)
$$

$r=$ koefisien antar variabel yang diharapkan $(0,546)$

$\mathrm{ln}=$ Fungsi longaritma "In" (M. Sopiyudin Dahlan, 2005, h.15).

$\mathrm{n}=\left\{\frac{Z \alpha+Z \beta}{0,5 \ln [(1+r) /(1-r)]}\right\}^{2}+3$

$\mathrm{n}=\left\{\frac{1,96+0,84}{0,5 \ln [(1+0,546) /(1-0,546)]}\right\}^{2}+3$

$\mathrm{n}=\frac{7,84}{0,22}+3$

$\mathrm{n}=38,6 \longrightarrow 39$ Sampel.

3. Pengambilan responden dengan cara simple random.

Analisis data yang digunakan pada penelitian ini yaitu:

1. Analisis Univariat

Analisis univariat untuk menjelaskan atau mendeskripsikan karakteristik setiap variabel penelitian (Soekidjo Notoatmodjo, 2010, h.182). Dalam penelitian ini menggunakan tabel distribusi pada variabel parameter jarak penampungan tinja dengan sumur gali, konstruksi sumur gali, perilaku pengguna sumur galiserta kualitas mikrobiologis (Coliform) air sumur gali.

\section{Analisis Bivariat}

Analisis bivariat dilakukan terhadap dua variabel yang diduga berhubungan. Metode analisis yang digunakan yaitu uji Regresi Linier.Regresi Linieruntuk menentukan besaran hubungan antar variabel, koefisien determinasi dan jika H0 ditolak lanjut ke persamaan garis. Menentukan besaran hubungan memiliki ketentuan sebagai berikut:

a. Range (jarak) hubungan antara $0 \mathrm{~s} / \mathrm{d} 1, \mathrm{R}=0$ berarti tidak ada hubungan sama sekali, $\mathrm{R}=1$ hubungan sempurna, semua $\mathrm{X}$ naik atau turun maka $\mathrm{Y}$ juga naik atau turun.

b. Cut Point (titik potong) diambil ditengah yaitu 0,5 , sehingga jika nilai $R=0,5$ hubungan moderat/menengah.

c. $<0,5$ hubungan lemah, $>0,5$ hubungan kuat.

\section{Instrumen}

Instrumen yang digunakan dalam penelitian ini adalah meteran, check list, alat tulis dan kamera.

\section{Hasil}

Desa Sumampir termasuk dalam wilayah Kecamatan Rembang Kabupaten Purbalingga bagian timur, tepatnya pada posisi $2^{0} 40^{\prime}-2^{0} 45^{\prime}$ Bujur Timur, dan $7^{0} 15^{\prime}-7^{0} 20^{\prime}$ Lintang Selatan. Desa Sumampir Kecamatan Rembang memiliki luas wilayah $575 \mathrm{Ha}$ yang secara administratif terbagi dalam 5 dusun dan 50 RT. Dilihat dari pemanfaatan lahan, sebagaian besar berupa tanah kering yaitu untuk pemukiman seluas 45 Ha (7,8\%), tegalan 232 Ha (40,3\%), sawah $180 \mathrm{Ha} \quad(31,3 \%)$, sedang sisanya terdiri dari 
perkebunan, tegalan, lahan usaha perikanan dan lainlain.Secara ekonomi, penduduk Desa Sumampir terdiri dari beberapa kelompok kerja (profesi), mulai dari petani, buruh tani, buruh industri, buruh bangunan, pengusaha, pedagang, angkutan, PNS, TNI/POLRI, pensiunan disamping itu ada juga yang pengangguran.

Jarak Penampungan Tinja dengan Sumur Gali di Desa Sumampir Kecamatan Rembang Kabupaten Purbalingga Tahun 2017

Berdasarkan table hasil pengukuran jarak penampungan tinja dengan sumur gali dari 39 sampel di Desa Sumampir, didapatkan hasil jarak lebih dari 11 meter sebanyak 8 (20,5\%) dan jarak kurang dari 11 meter sebanyak 31 (79,5\%).

Tabel 1.Hasil PengukuranJarak Penampungan Tinja dengan sumur gali di Desa Sumampir

Kecamatan Rembang Kabupaten Purbalingga Tahun 2017

\begin{tabular}{|c|c|c|}
\hline No. & Sampel & Jarak Penampungan Tinja \\
\hline 1. & TR & 7 \\
\hline 2. & ST & 9 \\
\hline 3. & SN & 13 \\
\hline 4. & SL & 1 \\
\hline 5. & $\mathrm{RB}$ & 2 \\
\hline 6. & IN & 9 \\
\hline 7. & MI & 8 \\
\hline 8. & $\mathrm{MN}$ & 9 \\
\hline 9. & SM & 7 \\
\hline 10. & MJ & 8 \\
\hline 11. & RO & 9 \\
\hline 12. & $\mathrm{AD}$ & 7 \\
\hline 13. & RY & 12 \\
\hline 14. & TY & 9 \\
\hline 15. & MR & 8 \\
\hline 16. & SE & 13 \\
\hline 17. & AT & 12 \\
\hline 18. & $\mathrm{MO}$ & 3 \\
\hline 19. & MS & 8 \\
\hline 20. & RI & 8 \\
\hline 21. & MU & 7 \\
\hline 22. & RT & 12 \\
\hline 23. & $\mathrm{EH}$ & 5 \\
\hline 24. & NI & 6 \\
\hline 25. & RN & 7 \\
\hline 26. & AW & 8 \\
\hline 27. & NT & 13 \\
\hline 28. & SR & 9 \\
\hline 29. & HM & 12 \\
\hline 30 & SG & 8 \\
\hline 31. & RW & 6 \\
\hline 32. & SR & 8 \\
\hline 33. & HW & 8 \\
\hline 34. & TO & 4 \\
\hline 35. & $\mathrm{TT}$ & 10 \\
\hline 36. & IS & 9 \\
\hline 37. & $\mathrm{TH}$ & 12 \\
\hline 38. & MW & 8 \\
\hline
\end{tabular}

39. RS 7

Tabel 2 Frekuensi Jarak Penampungan Tinja dengan Sumur Gali di Desa Sumampir Kecamatan Rembang Kabupaten Purbalingga Tahun 2017

\begin{tabular}{llrr}
\hline No. & $\begin{array}{l}\text { Jarak Penampungan } \\
\text { Tinja dengan Sumur } \\
\text { Gali }\end{array}$ & Jumlah & $\%$ \\
\hline \multicolumn{1}{c}{ Memenuhi Syarat } & 8 & 20,5 \\
2. & Tidak Memenuhi & 31 & 79,5 \\
& Syarat & & \\
\hline & Total & 39 & 100 \\
\hline
\end{tabular}

Kualitas Mikrobiologis (Coliform) Air Sumur Gali di Desa Sumampir Kecamatan Rembang Kabupaten Purbalingga Tahun 2017

Pada tabel 3 kualitas mikrobiologis (Coliform) air sumur gali dari 39 sampel air sumur gali yang diteliti, keseluruhan (100\%)>50 sel/100ml tidak memenuhi syarat.

Tabel 3.Hasil PemeriksaanKualitas Mikrobiologis

(Coliform) Air Sumur Gali di Desa Sumampir Kecamatan Rembang Kabupaten Purbalingga Tahun

\begin{tabular}{|c|c|c|}
\hline No. & Sampel & Coliform \\
\hline 1. & TR & 1100 \\
\hline 2. & ST & 1100 \\
\hline 3. & SN & 460 \\
\hline 4. & SL & $>2400$ \\
\hline 5. & $\mathrm{RB}$ & $>2400$ \\
\hline 6. & IN & 1100 \\
\hline 7. & MI & $>2400$ \\
\hline 8. & $\mathrm{MN}$ & 1100 \\
\hline 9. & SM & 1100 \\
\hline 10. & MJ & 1100 \\
\hline 11. & $\mathrm{RO}$ & 1100 \\
\hline 12. & $\mathrm{AD}$ & 1100 \\
\hline 13. & $\mathrm{RY}$ & 460 \\
\hline 14. & TY & 1100 \\
\hline 15. & MR & 1100 \\
\hline 16. & SE & $>2400$ \\
\hline 17. & AT & $>2400$ \\
\hline 18. & $\mathrm{MO}$ & 1100 \\
\hline 19. & MS & 1100 \\
\hline 20. & RI & 1100 \\
\hline 21. & MU & 1100 \\
\hline 22. & RT & 460 \\
\hline 23. & $\mathrm{EH}$ & $>2400$ \\
\hline 24. & NI & 1100 \\
\hline 25. & $\mathrm{RN}$ & $>2400$ \\
\hline 26. & AW & 1100 \\
\hline 27. & NT & 460 \\
\hline 28. & SR & 1100 \\
\hline 29. & HM & 1100 \\
\hline 30 & SG & 1100 \\
\hline 31. & RW & 460 \\
\hline 32. & SR & 1100 \\
\hline 33. & HW & 1100 \\
\hline 34. & TO & $>2400$ \\
\hline
\end{tabular}




\begin{tabular}{llc}
\hline 35. & TT & $>2400$ \\
36. & IS & $>2400$ \\
37. & TH & $>2400$ \\
38. & MW & 1100 \\
39. & RS & $>2400$ \\
\hline
\end{tabular}

Tabel 4 Frekuensi Kualitas Mikrobiologis (Coliform) Air Sumur Gali

\begin{tabular}{llrr}
\hline No. & $\begin{array}{c}\text { Kualitas Mikrobiologis } \\
\text { (Coliform) Air Sumur } \\
\text { Gali }\end{array}$ & $\begin{array}{c}\sum \\
\text { (jumlah) }\end{array}$ & $\begin{array}{r}\text { Perse } \\
\mathrm{n}(\%)\end{array}$ \\
\hline 1. & Memenuhi Syarat & 0 & 0 \\
2. & Tidak Memenuhi Syarat & 39 & 100 \\
\hline & Total & 39 & 100 \\
\hline
\end{tabular}

Konstruksi Sumur Gali di Desa Sumampir Kecamatan Rembang Kabupaten Purbalingga Tahun 2017

Berdasarkan tabel 4didapatkan hasil penelitian terhadap 39 sampel, konstruksi sumur gali yang memenuhi syarat sebanyak 1 (2.5\%) dan 38 (79,5) tidak memenuhi syarat.

Tabel 5Frekuensi Konstruksi Sumur Gali di Desa Sumampir Kecamatan Rembang Kabupaten Purbalingga Tahun 2017

\begin{tabular}{llrr}
\hline No. & Konstruksi Sumur Gali & Jumlah & \multicolumn{1}{c}{$\%$} \\
\hline 1. & Memenuhi Syarat & 1 & 2,5 \\
2. & Tidak Memenuhi & 38 & 79,5 \\
& Syarat & & \\
\hline & Total & 39 & 100 \\
\hline
\end{tabular}

\section{Adapun variabel-variabel konstruksi sumur gali:}

1. Kondisi Lantai Sumur Gali

Tabel 6 Frekuensi Kondisi Lantai Sumur Gali Di Desa Sumampir Kecamatan Rembang Kabupaten Purbalingga Tahun 2017

\begin{tabular}{clcc}
\hline No. & Kondisi Lantai Sumur Gali & Jumlah & $\%$ \\
\hline 1. & Memenuhi Syarat & 16 & 41 \\
2. & Tidak Memenuhi Syarat & 23 & 59 \\
\hline & Total & 39 & 100 \\
\hline
\end{tabular}

Pada tabel 6 didapatkan data lantai kedap air minimal 1 meter dari sumur, tidak retak atau bocor, mudah dibersihkan, dan tidak tergenang air (kemiringan minimal 1-5 ${ }^{0}$ di Desa Sumampir Kecamatan Rembang Kabupaten Purbalingga dengan 39 responden yaitu 16 (41\%) responden memenuhi syarat dan 23 (59\%) responden tidak memenuhi syarat.

2. Bibir sumur gali

Tabel 7Frekuensi Bibir Sumur Gali di Desa Sumampir Kecamatan Rembang Kabupaten Purbalingga Tahun 2017

\begin{tabular}{clcc}
\hline No. & Kondisi Bibir Sumur Gali & Jumlah & $\%$ \\
\hline 1. & Memenuhi Syarat & 30 & 76,9
\end{tabular}

2. Tidak Me-menuhi Syarat $\quad 9 \quad 23,1$

Pada tabel 7 didapatkan data bibir sumur, tinggi sumur, minimal $80 \mathrm{~cm}$ dari lantai, dibuat dari bahan yang kuat dan rapat air di Desa Sumampir Kecamatan Rembang Kabupaten Purbalingga dengan 39 responden yaitu 30 (76,9\%) responden memenuhi syarat dan $9(23,1 \%)$ responden tidak memenuhi syarat.

3. Dinding sumur gali

Tabel 8Frekuensi Dinding Sumur Gali di Desa Sumampir Kecamatan Rembang Kabupaten Purbalingga Tahun 2017

\begin{tabular}{|c|c|c|c|}
\hline No. & $\begin{array}{l}\text { Kondisi Dinding Sumur } \\
\text { Gali }\end{array}$ & Jumlah & $\%$ \\
\hline 1. & Memenuhi Syarat & 26 & 66,7 \\
\hline 2. & Tidak Memenuhi Syarat & 13 & 33,3 \\
\hline & Total & 39 & 100 \\
\hline
\end{tabular}

Pada tabel 8 didapatkan data dinding sumur minimal dalamnya 3 meter dari lantai, dibuat dari bahan kedap air dan kuat (tidak retak dan tidak longsor di Desa Sumampir Kecamatan Rembang Kabupaten Purbalingga yaitu 26 (66,7\%) memenuhi syarat dan 13 $(33,3 \%)$ tidak memenuhi syarat.

\section{Tutup Sumur Gali}

Tabel 9Frekuensi Tutup Sumur Gali Di Desa Sumampir Kecamatan Rembang Kabupaten Purbalingga Tahun 2017

\begin{tabular}{llcc}
\hline No. & $\begin{array}{l}\text { Kondisi Tutup Sumur } \\
\text { Gali }\end{array}$ & Jumlah & $\%$ \\
\hline 1. & Tertutup rapat & 5 & 12.8 \\
2. & Tidak Tertutup Rapat & 34 & 87.2 \\
\hline \multicolumn{2}{r}{ Total } & 39 & 100 \\
\hline
\end{tabular}

Pada tabel 9 didapat hasil kondisi tutup sumur jika pengambilan air sumur gali dengan pompa tangan/ listrik, ditutup rapattertutup rapat sebanyak 5 (12,8\%) dan sebanyak $34(87,2 \%)$ sampel tidak tertutup rapat.

\section{Perilaku Pengguna Sumur Gali}

Berdasarkan tabel 10 hasil penilaian perilaku pengguna sumur gali di Desa Sumampir Kecamatan Rembang Kabupaten Purbalingga dari 39 sampel, hanya hanya 1 (2.5\%) yang masuk dalam kategori baik dan 38(97.5\%) masuk dalam kategori tidak baik.

Tabel 10 Frekuensi Perilaku Pengguna Sumur Gali di Desa Sumampir Kecamatan Rembang Kabupaten Purbalingga Tahun 2017

\begin{tabular}{clcc}
\hline No. & $\begin{array}{l}\text { Perilaku Pengguna Sumur } \\
\text { Gali }\end{array}$ & Jumlah & $\%$ \\
\hline 1. & Baik & 1 & 2.5
\end{tabular}




\begin{tabular}{lll} 
& 38 & 97.5 \\
\hline Total & 39 & 100
\end{tabular}

\section{Adapun variabel-variabel perilaku pengguna} sumur gali:

\section{a. Teknik pengambilan air sumur gali}

1) Penggunaan kerekan pada sumur gali

Tabel 11Frekuensi Penggunaan Kerekan Pada Sumur Gali di Desa Sumampir Kecamatan Rembang Kabupaten Purbalingga Tahun 2017

\begin{tabular}{clcc}
\hline No. & Penggunaan Kerekan & Jumlah & $\%$ \\
\hline 1. & $\begin{array}{l}\text { Kerekan Lebih Tinggi Dari } \\
\text { Bibir Sumur }\end{array}$ & 6 & 15.3 \\
2. & $\begin{array}{l}\text { Kerekan Lebih Rendah } \\
\text { Dari Bibir Sumur }\end{array}$ & 33 & 84.7 \\
\hline \multicolumn{2}{c}{ Total } & 39 & 100 \\
\hline
\end{tabular}

Pada tabel 11diperoleh hasil penelitian terhadap 39 sampel yang menggunakan kerekan lebih tinggi dari bibir sumur sebanyak 6 (15.3\%) dan menggunakan kerekan lebih rendah dari bibir sumur adalah sebanyak $33(84.7 \%)$.

2) Ember dan Tali

Tabel 12 Frekuensi Ember dan Tali di Desa Sumampir Kecamatan Rembang Kabupaten Purbalingga Tahun

\begin{tabular}{clcc}
\multicolumn{4}{c}{2017} \\
\hline No. & Kondisi Ember Dan Tali & Jumlah & $\%$ \\
\hline 1. & Selalu Menggantung & 6 & 15.3 \\
2. & Tidak Selalu Menggantung & 33 & 84.7 \\
\hline \multicolumn{2}{c}{ Total } & 39 & 100 \\
\hline
\end{tabular}

Pada tabel 12 didapatkan hasil penelitian terhadap 39 sampel,terdapat 6 (15.3\%) sampel dengan kondisi ember dan tali selalu menggantung dan tali ember tidak selalu menggantung sebanyak 33 (84.7\%) sampel.

\section{3) Penggunaan Timba}

Tabel 13 Frekuensi Penggunaan Timba di Desa

Sumampir Kecamatan Rembang Kabupaten Purbalingga Tahun 2017

\begin{tabular}{clcc}
\hline No. & Penggunaan Timba & Jumlah & $\%$ \\
\hline 1. & Khusus & 35 & 89,7 \\
2. & Tidak Khusus & 4 & 10,3 \\
\hline \multicolumn{2}{r}{ Total } & 39 & 100 \\
\hline
\end{tabular}

Pada tabel 13 didapatkan hasil penelitian yang menggunakan timba khusus sebanyak 35 (89,3\%) sampel dan tidak menggunakan timba khusus sebanyak 4 (20,3\%) sampel.

\section{b. Pengangkutan air sumur gali}

1) Ember/ wadah
Berdasarkan penelitian diperoleh hasil kondisi ember/ wadah air di Desa Sumampir Kecamatan Rembang Kabupaten Purbalingga Tahun 2017, ember/ wadah air bersih sebanyak 14 (35.9\%) dan 25 (64.1\%) kondisi ember tidak bersih, sedangkan kondisi ember/ wadah air terdapat tutup sebanyak 1 (5.1\%) dan kondisi ember tidak terdapat tutup sebanyak 37 (94.9\%) sampel.

2) Pipa untuk mengalirkan air

Tabel 14 Frekuensi Pipa Untuk Mengalirkan Air di Desa Sumampir Kecamatan Rembang Kabupaten Purbalingga Tahun 2017

\begin{tabular}{|c|c|c|c|}
\hline No. & Penggunaan Timba & Jumlah & $\%$ \\
\hline 1. & Khusus & 12 & 30,8 \\
\hline 2. & Bocor & 27 & 69,2 \\
\hline & Total & 39 & 100 \\
\hline
\end{tabular}

Pada tabel 14 diperoleh hasil penelitian terhadap 39 sampel, kondisi pipa untuk mengalirkan air tidak bocor sebanyak 12 (30,8\%) dan kondisi pipa untuk mengalirkan air bocor sebanyak 27 (69,2\%) sampel.

3) Tangki Air

Tabel 15 Frekuensi Tangki Air di Desa Sumampir Kecamatan Rembang Kabupaten Purbalingga Tahun

\begin{tabular}{clcc}
\multicolumn{4}{c}{2017} \\
\hline No. & Kondisi Tangki Air & Jumlah & $\%$ \\
\hline 1. & Selalu Bersih & 4 & 15.3 \\
2. & Tidak Selalu Bersih & 35 & 84.7 \\
\hline \multicolumn{2}{c}{ Total } & 39 & 100 \\
\hline
\end{tabular}

Pada tabel 15 diperoleh hasil penelitian terhadap 39 sampel, kondisi tangki air selalu bersih sebanyak 4 (10.3\%) dan kondisi tangki air tidak selalu bersihsebanyak 35 (89.7\%) sampel.

\section{c. Penyimpanan air}

1) Ember/ wadah air

Berdasarkan hasil penelitian di Desa Sumampir Kecamatan Rembang Kabupaten Purbalingga Tahun 2017 sebanyak 3 (7.7\%) ember/ wadah air ada tutup, ember/ wadah air tidak ada tutup sebanyak 36 (92.3\%) sampel danember/ wadah air bersih sebanyak 10 (25.6\%), tidak bersih sebanyak 29 (74.4\%), Ember/ wadah air keseluruhan (100\%) tidak berdekatan dengan tempat sampah.

Hubungan Jarak Penampungan Tinja dengan Kualitas Mikrobiologis (Coliforrm) Air Sumur Gali

Tabel 16 Statistik Hubungan Jarak Penampungan Tinja dengan Kualitas Mikrobiologis (Coliform) Air Sumur Gali

\begin{tabular}{cc}
\hline Variabel & $\rho$ \\
\hline Jarak Penampungan Tinja & 0,09
\end{tabular}


Pada tabel 16 diperoleh nilai $\rho$ 0,09> 0,05, sehingga tidak ada hubungan jarak penampungan tinja dengan kualitas mikrobiologis (Coliform) air sumur gali

\section{Hubungan Konstruksi Sumur Gali dengan Kualitas Mikrobiologis (Coliforrm) Air Sumur Gali}

Tabel 17Statistik Hubungan Konstruksi Sumur Gali dengan Kualitas Mikrobiologis (Coliform) Air Sumur Gali

\begin{tabular}{cc}
\hline Variabel & $\rho$ \\
\hline Konstruksi Sumur Gali & 0,166 \\
\hline
\end{tabular}

Pada tabel 17 diperoleh nilai $0,166>0,05$, sehingga tidak ada hubungan konstruksi sumur gali dengan kualitas mikrobiologis (Coliform) air sumur gali.

\section{Hubungan Perilaku Pengguna Sumur Gali dengan Kualitas Mikrobiologis (Coliform) Air Sumur Gali}

Tabel 18Statistik Hubungan Perilaku Pengguna Sumur Gali dengan Kualitas Mikrobiologis (Coliform) Air

\begin{tabular}{cc}
\multicolumn{2}{c}{ Sumur Gali } \\
\hline Variabel & $\mathrm{P}$ \\
\hline Perilaku Pengguna Sumur Gali & 0,649 \\
\hline
\end{tabular}

Pada tabel 18 diperoleh nilai 0 0,649 > 0,05, sehingga tidak ada hubungan perilaku pengguna sumur gali dengan kualitas mikrobiologis (Coliform) air sumur gali.

\section{Pembahasan}

Desa Sumampir termasuk dalam wilayah Kecamatan Rembang Kabupaten Purbalingga bagian timur, tepatnya pada posisi $2^{0} 40^{\prime}-2^{0} 45^{\prime}$ Bujur Timur, dan $7^{0} 15^{\prime}-7^{0} 20^{\prime}$ Lintang Selatan. Desa Sumampir Kecamatan Rembang memiliki luas wilayah 575 Ha yang secara administratif terbagi dalam 5 dusun dan 50 RT. Dilihat dari pemanfaatan lahan, sebagaian besar berupa tanah kering yaitu untuk pemukiman seluas 45 Ha (7,8\%), tegalan 232 Ha (40,3\%), sawah $180 \mathrm{Ha}(31,3 \%)$, sedang sisanya terdiri dari perkebunan, tegalan, lahan usaha perikanan dan lainlain.Secara ekonomi, penduduk Desa Sumampir terdiri dari beberapa kelompok kerja (profesi), mulai dari petani, buruh tani, buruh industri, buruh bangunan, pengusaha, pedagang, angkutan, PNS, TNI/POLRI, pensiunan disamping itu ada juga yang pengangguran.

\section{Jarak Penampungan Tinja dengan Sumur Gali di Desa Sumampir Kecamatan Rembang Kabupaten Pubalingga Tahun 2017}

Berdasarkan hasil pengukuran jarak penampungan tinja dengan sumur gali dari 39 sampel di Desa Sumampir, didapatkan hasil jarak lebih dari 11 meter sebanyak 8 (20,5\%) dan jarak kurang dari 11 meter sebanyak 31 (79,5\%).

Menurut Lud Waluyo (2005, h.155), persyaratan kesehatan yang harus dipenuhi oleh sarana sumur gali khususnya mengenai jarak sumur gali yaitu jarak sumur gali minimal $11 \mathrm{~m}$ dari sumber pencemar seperti jamban, air kotor atau comberan, tempatpembuangan sampah, kandang ternak serta tempat kotoran ternak. Jarak tersebut diharapkan pergerakan bakteri Coliform tidak dapat menembus kedalam sumur gali.

\section{Kualitas Mikrobiologis (Coliform) Air Sumur Gali \\ Berdasarkan hasil penelitian kandungan} mikrobiologis (Coliform) air sumur gali dari 39 sampel air sumur gali yang diteliti, keseluruhan (100 $\%)$ tidak memenuhi syarat.

Standar kualitas air bersih sesuai ketentuan Permenkes RI No. 416/MENKES/PER/IX/1990, bakteri golongan Coliform untuk air non perpipaan berdasarkan nilai MPN yang memenuhi syarat adalah 50/100 ml untuk dapat dijadikan sebagai air yang layak dikonsumsi.

Kandungan bakteri golongan Coliform ini dipakai sebagai patokan utama menentukan apakah air bersih memenuhi syarat mikrobiologis atau tidak karena umumnya hidup di dalam pencernaan manusia atau hewan berdarah panas. Bakteri Coliform dipakai sebagai indikator organisme karena mudah ditemukan dengan cara yang sederhana, tidak berbahaya, sulit hidup lebih lama dari pada patogen yang lainnya (Totok dalam ulfatuzzahroh, 2016, h.60).

Jika dilihat dari kandungan mikrobiologis (Coliform) air sumur gali di Desa Sumampir yang keseluruhan $100 \%$ tidak memenuhi syarat, dapat disebabkan karena kondisi fisik penampungan tinja, konstruksi sumur gali dan perilaku pengguna sumur gali yang tidak saniter. Hal ini sesuai dengan teori bahwa faktor yang mempengaruhi penyebaran bakteri Coliform dari sumber pencemar kedalam sumur gali antara lain, jenis tanah, aliran air tanah, kondisi fisik penampungan tinja (Fawanri Herwin Sinabang, 2009, h.20).

Berbagai upaya dan tindakan dapat dilakukan untuk memperbaiki kandungan mikrobiologis (Coliform) air sumur gali antara lain memperbaiki kondisi fisik penampungan tinja. Kondisi fisik penampungan tinja dapat menyebabkan pencemaran air, karena bakteri Coliform yang terdapat di dalam penampungan tinja dapat keluar dari penampungan tinja apabila kondisi fisik penampungan tinja tidak memenuhi syarat (Fawanri Herwin Sinabang, 2009, h.20).

Penyakit yang berhubungan dengan kandungan Coliform air sumur gali salah satunya adalah penyakit diare yang memang di Desa Sumampir adalah Diare tertinggi di Kabupaten Purbalingga.Kondisi tersebut sesuai dengan teori tentang penyakit yang menyerang manusia dapat ditularkan dan menyebar secara langsung maupun tidak langsung melalui air. Penyakit 
yang ditularkan melalui air disebut sebagai water borne disease atau water wash disease. Diantara penyakit tersebut adalah kolera, diare, disentri, tifoid dan sebagainya (Lud Waluyo, 2005).

\section{Konstruksi Sumur Gali di Desa Sumampir Kecamatan Rembang Kabupaten Purbalingga Tahun 2017}

Berdasarkan tabel hasil penelitian terhadap 39 sampel, konstruksi sumur gali yang memenuhi syarat sebanyak hanya 1 (2.5\%) yang masuk dalam kategori baik dan 38(97.5\%) masuk dalam kategori tidak baik.

Enjtang dalam Ulfatuzzahroh (2016, h.57) mengemukakan bahwa kondisi lokasi dan konstruksi sumur gali yang tidak memenuhi syarat dapat meningkatkan tingkat resiko pencemaran sumber air bersih, keadaan konstruksi yang tidak memenuhi persyaratan minimal menandakan adanya risiko kontaminasi sumber air bersih oleh pencemar, semakin banyak parameter lokasi dan konstruksi sumur gali yang tidak memenuhi persyaratan akan semakin tinggi tingkat risiko pencemaran, maka semakin banyak kemungkinan kontaminasi yang berasal dari sekitar sumber sehingga dapat menurunkan kualitas air.

Tidak memenuhinya syarat konstruksi sumur dapat disebabkan oleh beberapa faktor diantaranya kondisi perekonomian yang menggunakan sumur sebagai sumber air dimana untuk membuat sumur dengan konstruksi sumur yang memenuhi syarat membutuhkan dana yang lebih besar.

Pembangunan sumur gali harus mengikuti standar kesehatan, bangunan fisik sumur yang tidak memenuhi standar akan mempermudah bakteri meresap dan masuk ke dalam sumur gali. Menurut Lud Waluyo (2005, h.155) yang harus dipenuhi oleh sarana sumur gali adalah sebagai berikut:

a. Lantai harus kedap air minimal 1 meter dari sumur, tidak retak/ bocor, mudah dibersihkan, dan tidak tergenang air (kemiringan minimal 1\%-5\%)

b. Bibir sumur, tinggi bibir sumur minimal $80 \mathrm{~cm}$ dari lantai, dibuat dari bahan yang kuat dan rapat air

c. Dinding sumur minimal dalamnya 3 meter dari lantai, dibuat dari bahan kedap air dan kuat (tidak retak dan tidak longsor).

\section{Perilaku Pengguna Sumur Gali di Desa Sumampir Kecamatan Rembang Kabupaten Purbalingga Tahun 2017}

Berdasarkan hasil penelitian terhadap perilaku pengguna sumur gali di Desa Sumampir Kecamatan Rembang Kabupaten Purbalingga dari 39 sampel, hanya hanya 1 (2.5\%) yang masuk dalam kategori baik dan 38(97.5\%) masuk dalam kategori tidak baik.

Pencemaran kembali sangat tergantung pada tingkah laku atau kebiasaan masyarakat atau orang dalam penanganan air bersih. Tahap-tahap tersebut, antara lain:

a. Pengambilan air dan sarana air bersih misalnya sumur gali dapat memakai timba. Apabila pengambilan air dengan timba, maka timba tersebut harus timba khusus untuk sumur itu. Tali timbanya tersebut harus timba khusus untuk sumur itu. Tali timbanya tetap bersih dan setelah selesai dipakai maka timba dan tali harus digantung pada gantungan tertentu. Timba tali tidak boleh diletakkan di lantai sumur.

b. Pengangkutan air dapat memakai ember atau tempat atau wadah air atau gentong dan lain-lain yang bersih. Wadah air harus tertutup, jangan dimasukkan benda-benda atau daun-daun (biasanya dipakai untuk mencegah tumpah dalam perjalanan). Pipa atau selang yang digunakan untuk mengalirkan air jangan ada kebocoran dan tidak terendam dalam air yang kotor. Tangki air atau sejenisnya perlu diperhatikan agar tangki tersebut selalu bersih, dan jangan digunakan untuk mengangkut air kotor atau cairan lain, selang dari tangki tersebut harus selalu bersih.

c. Penyimpanan air di rumah biasanya menggunakan gentong atau tempayan. Gentong atau tempayan harus mempunyai tutup yang rapat, bersih dan mudah dibersihkan. Paling sedikit setiap satu minggu supaya dibersihkan atau dikuras. Tempayan ditempatkan di tempat yang tidak mudah tercemari dari lantai, jauh dari tempat sampah. Pengambilan air dari tempat penyimpanan dapat menggunakan kran atau gayung. Apabila menggunakan gayung, gayung tersebut harus bersih setelah pengambilan air selesai, tempat penyimpanan tersebut ditutup kembali (Lud Waluyo, 2005).

\section{Hubungan Jarak Penampungan Tinja dengan Kualitas Mikrobiologis (Coliform) Air Sumur Gali di Desa Sumampir Kecamatan Rembang Kabupaten Purbalingga Tahun 2017}

Hasil analisis bivariat menggunakan uji regresi liniermemiliki nilai sig $(\rho)=0,09>0,05$, sehingga tidak ada hubungan yang signifikan antara jarak penampungan tinja dengan kualitas mikrobiologis (coliform) air sumur gali di Desa Sumampir Kecamatan Rembang Kabupaten Purbalingga Tahun 2017.

Hasil berbeda dengan penelitian sebelumnya, kemungkinan disebabkan oleh keterbatasan peneliti antara lain penanganan sampel dan pengiriman sampel, dimana lokasi penelitian jauh dari tempat pemeriksaan kualitas mikrobiologis (Coliform) air sumur gali sehingga memerlukan waktu yang lama untuk sampai ke tempat tersebut serta suhu yang memungkinkan perkembangbiakan bakteri Coliform.

Waktu yang diperlukan setiap jenis bakteri untuk berkembangbiak berbeda-beda, tetapi biasanya berkisar 15-30 menit pada kondisi ideal (Hiasinta A, 
2001, h.53). Pola pertumbuhan bakteri dapat sangat dipengaruhi oleh suhu. Bakteri tumbuh pada kisaran suhu tertentu seperti bakteri psikrofil dapat tumbuh pada kisaran suhu $0{ }^{0} \mathrm{C}-30{ }^{0} \mathrm{C}$, bakteri mesofil dapat tumbuh pada kisaran suhu $25^{\circ} \mathrm{C}-40^{\circ} \mathrm{C}$ dan bakteri termofil dapat tumbuh $>50^{\circ} \mathrm{C}$. Bakteri Coliform termasuk dalam kelompok bakteri mesofil dengan suhu minimum $10-15{ }^{0} \mathrm{C}$, suhu optimum $30-40{ }^{\circ} \mathrm{C}$ dan suhu maksimum $40-50{ }^{\circ} \mathrm{C}$ (Lud Waluyo, 2005, h.17).

\section{Hubungan Konstruksi Sumur Gali dengan Kualitas Mikrobiologis (Coliform) Air Sumur Gali di Desa Sumampir Kecamatan Rembang Kabupaten Purbalingga Tahun 2017}

Hasil analisis bivariat menggunakan uji regresi liniermemiliki nilai sig $(\rho)=0,166>0,05$, sehingga tidak ada hubungan yang signifikan antara konstruksi sumur gali dengan kualitas mikrobiologis (coliform) air sumur gali di Desa Sumampir Kecamatan Rembang Kabupaten Purbalingga Tahun 2017.

Hasil penelitian Heriani Hasnawi (2014) tidak ada pengaruh konstruksi sumur gali ditinjau dari aspek lantai terhadap kandungan mikrobiologis pada air sumur gali dengan nilai $\rho=0.31>0.05$.

Faktor yang mempengaruhi penyebaran bakteri Coliform dari sumber pencemar ke dalam sumur gali antara lain jenis tanah, aliran air tanah dan kondisi fisik penampungan tinja (Fawanri Herwin Sinabang, 2009, h.20).

Jenis tanah yang berbeda akan berbeda pula daya kandungan dan daya melewatnya air. Daya kandungan atau kemampuan tanah untuk menyimpan air disebut porositas. Umumnya dinyatakan dalam prosen atau rasio antara pori-pori tanah dengan volume total tanah. Kemampuan tanah untuk melewatkan air disebut permaebilitas yaitu jumlah air yang dapat dilewatkan oleh lapisan tanah dalam satuan luas penampang.

Aliran air tanah yang didalam siklus hidrologi, air tanah secara alami mengalir karena adanya tekanan dan letak ketinggian lapisan tanah. Air akan mengalir dari tempat yang tinggi ke tempat yang rendah. Oleh karena itu, apabila letak sumur gali berada di bawah dari letak sumber pencemar maka bahan pencemar bersama aliran air tanah akan mengalir untuk kemudian mencapai sumur gali.

Kondisi fisik penampungan tinja dapat menyebabkan pencemaran air, karena bakteri Coliform yang terdapat di dalam penampungan tinja dapat keluar dari penampungan tinja apabila kondisi fisik penampungan tinja tidak memenuhi syarat.

\section{Hubungan Perilaku Pengguna Sumur Gali Dengan Kualitas Mikrobiologis (Coliform) Air Sumur Gali di Desa Sumampir Kecamatan Rembang Kabupaten Purbalingga Tahun 2017 \\ Hasil analisis bivariat menggunakan uji regresi liniermemiliki nilai sig $(\rho)=0,649>0,05$, sehingga tidak ada hubungan yang signifikan antara perilaku pengguna sumur gali dengan kualitas mikrobiologis}

(coliform) air sumur gali di Desa Sumampir Kecamatan Rembang Kabupaten Purbalingga Tahun 2017.

Hasil berbeda dengan penelitian sebelumnya, kemungkinan disebabkan oleh keterbatasan peneliti antara lain penanganan sampel dan pengiriman sampel, dimana lokasi penelitian jauh dari tempat pemeriksaan kualitas mikrobiologis (Coliform) air sumur gali sehingga memerlukan waktu yang lama untuk sampai ke tempat tersebut serta suhu yang memungkinkan perkembangbiakan bakteri Coliform.

Waktu yang diperlukan setiap jenis bakteri untuk berkembangbiak berbeda-beda, tetapi biasanya berkisar 15-30 menit pada kondisi ideal (Hiasinta A, 2001, h.53). Pola pertumbuhan bakteri dapat sangat dipengaruhi oleh suhu. Bakteri tumbuh pada kisaran suhu tertentu seperti bakteri psikrofil dapat tumbuh pada kisaran suhu $0{ }^{\circ} \mathrm{C}-30{ }^{\circ} \mathrm{C}$, bakteri mesofil dapat tumbuh pada kisaran suhu $25^{\circ} \mathrm{C}-40^{\circ} \mathrm{C}$ dan bakteri termofil dapat tumbuh $>50^{\circ} \mathrm{C}$. Bakteri Coliform termasuk dalam kelompok bakteri mesofil dengan suhu minimum $10-15{ }^{\circ} \mathrm{C}$, suhu optimum $30-40{ }^{\circ} \mathrm{C}$ dan suhu maksimum $40-50{ }^{\circ} \mathrm{C}$ (Lud Waluyo, 2005, h.17).

\section{Kesimpulan}

1.Jarak penampungan tinja dengan sumur gali di Desa Sumampir, didapatkan hasil jarak lebih dari 11 meter (memenuhi syarat) sebanyak 8 (20,5\%) dan jarak kurang dari 11 meter (tidak memenuhi syarat) sebanyak 31 (79,5\%). Hasil mean 8.23, median 8.00, standar deviasi 2.870, nilai minimal 1 dan nilai maksimal 13 pada jarak penampungan tinja di Desa Sumampir Kecamatan Rembang Kabupaten Purbalingga Tahun 2017

2. Kualitas mikrobiologis (Coliform) air sumur gali $100 \%$ tidak memenuhi syarat di Desa Sumampir Kecamatan Rembang Kabupaten Purbalingga Tahun 2017.

3. Nilai Sig $(\rho)$ 0.09>0.05, sehingga tidak ada hubungan yang signifikan antara jarak penampungan tinja dengan kualitas mikrobiologis (Coliform) air sumur gali.

4. Nilai Sig $(\rho) 0.166>0.05$, sehingga tidak ada hubungan yang signifikan antara konstruksi sumur gali dengan kualitas mikrobiologis (Coliform) air sumur gali di Desa Sumampir Kecamatan Rembang Kabupaten Purbalingga Tahun 2017.

\section{Saran}

1. Bagi Puskesmas

a. Memberikan penyuluhan tentang sanitasi (jarak sumber pencemar ke sumur gali yang memenuhi syarat kesehatan, kualitas mikrobiologis air sumur gali, konstruksi sumur gali dan cara penggunaan sumur gali) dalam rangka meningkatkan taraf kesehatan dibidang kesehatan lingkungan. 
b. Pemantauan sanitasi sumur gali dan pemeriksaan kualitas mikrobiologis (Coliform) air sumur gali.

2. Bagi Masyarakat

Masyarakat harus memperhatikan keadaaan sanitasi di sekitar sumur gali, dengan selalu menjaga kebersihan sumur gali.

\section{Daftar Pustaka}

Aris Santjaka, 2011, Statistik Untuk Penelitian Kesehatan, Yogyakarta: Nuha Medika

Budiman Chandra, 2007, Pengantar Kesehatan Lingkungan, Jakarta: Penerbit Buku Kedokteran EGC

Danang Kusjuliadi P, 2007, Septictank, Jakarta: Penebar Swadaya

Dinas Kesehatan Kota Purbalingga, 2015, Profil Kesehatan Kabupaten Purbalingga, Purbalingga

Fawanri Herwin Sinabang, 2009, Studi Kualitas Mikrobiologis Air Sumur Gali di Kelurahan Larangan Kecamatan Larangan Kabupaten Brebes Tahun 2009, KTI, Purwokerto: Jurusan Kesehatan Lingkungan Purwokerto

Frisian Lufti Intan R, 2016, Hubungan Antara Jarak Sumber Pencemar Dengan Kualitas Mikrobiologis Air Sumur Gali di Desa Pangebatan Kecamatan Karanglewas Kabupaten Banyumas Tahun 2016, Karya Tulis Ilmiah, Purwokerto: Politeknik Kesehatan Kemenkes Semarang Jurusan Kesehatan Lingkungan Purwokerto

Heriyani Hasnawi, 2014, Pengaruh Konstruksi Sumur Terhadap Kandungan Bakteri Eschercia Coli Pada Air Sumur Gali Di Desa Dopalak Kecamatan Paleleh Kabupaten Boul, Gorontalo: Universitas Negeri Gorontalo

Hiasinta A. Purnawijayanti, 2001, Sanitasi Hygiene dan Keselamatan Kerja Dalam Pengelolaan Makanan, Jakarta: Kanisius

Lud Waluyo, 2005, Mikrobiologi Lingkungan, Malang: Universitas Muhammadiyah Malang

M. Sopiyudin Dahlan, 2005, Besar Sampel dalam Penelitian Kedokteran dan Kesehatan, Jakarta: Arkans

Novel H. Tendean, 2012, Hubungan Antara Jarak Sumber Pencemar Dengan Kandungan Bakteri Coliform Pada Air Sumur Gali Di Desa Kapitu Kecamatan Amurang Barat Kabupaten
Minahasa Selatan, Manado: Fakultas Kesehatan Masyarakat Universitas Sam Ratulangi Manado

Nurmala Febrianti Radjak, 2013, Pengaruh Jarak Septic Tank dan Kondisi Fisik Sumur terhadap keberadaan Bakteri Escheria coli pada Sumur Gali di Desa Molohu Kecamatan Tolangohula Kabupaten Gorontalo, Jurnal, Gorontalo: Fakultas Ilmu Kesehatan dan Keolahragaan Universitas Negeri Gorontalo

$\begin{array}{lrr}\text { Kesehatan } & \text { 1990, Peraturan } & \text { Menteri } \\ \text { RI } & \text { Nomor }\end{array}$

Peraturan Pemerintah RI Nomor 82 Tahun 2001, Pengendalian Kualitas Air dan Pengendalian Pencemaran Air

Puskesmas Rembang, 2015, Laporan Tahunan Puskesmas Rembang, Rembang

Rahayu Sri Pujiati, 2010 PengaruhJarak Sumur Gali dengan Septic Tank Terhadap Kandungan Bakteri Coliform Pada Air Sumur Gali Di Kelurahan Citrodiwangsa, Kecamatan Lumajang, Kabupaten Lumajang, jurnal IKESMA Vol. 6

Soeparman \& Suparmin, 2002, Pembuangan Tinja dan Limbah Cair, Jakarta: Penerbit Buku Kedokteran EGC

Sumur Sehat, www.helpingpeopleideas.com

Suharsimi Arikunto, 1998, Prosedur Penelitian Suatu Pendekatan Praktik, Jakarta: PT Rineka Cipta

Suharsimi Arikunto, 2006, Prosedur Penelitian Suatu Pendekatan Praktik, Jakarta: PT Rineka Cipta

Soekidjo Notoatmodjo, 2010, Metode Penelitian Kesehatan, Jakarta: Asti Mahasatya

Tri Cahyono, 2014, Pedoman Penulisan Proposal dan Karya Tulis Ilmiah, Purwokerto: JKL Kemenkes Purwokerto

Ulfatuzzahroh, 2016, Hubungan antara Konstruksi dengan Kandungan Bakteri Coliform Air Sumur Gali di Desa Pangebatan Kecamatan Karanglewas Kabupaten Banyumas Tahun 2016, Karya Tulis Ilmiah, Purwokerto: Politeknik Kesehatan Kemenkes Semarang Jurusan Kesehatan Lingkungan Purwokerto

Undang-Undang Republik Indonesia Nomor 7 Tahun 2004 Sumber Daya Air 